Newfoundland and Labrador Studies

\title{
Mary Walsh. Crying for the Moon
}

\section{Francesca Boschetti}

Volume 33, numéro 2, 2018

URI : https://id.erudit.org/iderudit/1058083ar

DOI : https://doi.org/10.7202/1058083ar

Aller au sommaire du numéro

Éditeur(s)

Faculty of Arts, Memorial University

ISSN

1719-1726 (imprimé)

1715-1430 (numérique)

Découvrir la revue

Citer ce compte rendu

Boschetti, F. (2018). Compte rendu de [Mary Walsh. Crying for the Moon].

Newfoundland and Labrador Studies, 33(2). https://doi.org/10.7202/1058083ar d'utilisation que vous pouvez consulter en ligne.

https://apropos.erudit.org/fr/usagers/politique-dutilisation/ 
It is to the curator's credit that the text does not overwhelm the publication. The writing by all contributors is succinct and useful but allows the artwork to speak for itself.

Charlotte Jones (retired) Grenfell Campus Art Gallery, Memorial University of Newfoundland

Mary Walsh. Crying for the Moon. Toronto: HarperCollins, 2017. ISBN 978-1-44341-036-6

Crying for the Moon (2017) is Mary Walsh's debut novel, published after decades of award-winning work as an actress, comedian, director, producer, and social activist. Both Bildungsroman and murder mystery, it concentrates on Maureen Brennan, a teenager born in St. John's, Newfoundland. Love, physical and emotional abuse, teenage pregnancy, alcoholism, and drugs are all themes explored in the novel. Maureen's struggle to gain emotional strength is in fact intensified by the dysfunctional environment in which she lives, the people who surround her, and the choices she makes.

The main sections of the novel are preceded by a brief prologue set in 1970, where we learn of how Maureen has poisoned the food in the fridge following one of her violent boyfriend Bo's beatings. The prologue then is followed by three parts. Part 1 begins with Maureen's successful attempt to join her religious school's choir so that she can attend Expo 67 in Montreal. The second daughter of a strict, abusive mother and of a distant and often drunk father, she lives at her family home on Princess Street with her parents and disabled sister. Once she reaches Montreal, Maureen visits disreputable pubs with her friend Carleen and ends up pregnant. Back in St. John's, she is sent away 
from school and forced to give up her child for adoption. Part 2 concentrates on Maureen's involvement with boyfriend Bo and the St. John's drug scene, and ends with her discovery that her baby was adopted by a family in Montreal. In closing the novel, Part 3 focuses on the resolution of Bo's murder investigation and Maureen's departure for Montreal in search of her baby with a new boyfriend, George.

Maureen's internal monologue pervades most of the novel and helps the reader empathize with the character. Walsh succeeds in making her readers feel like they are in Maureen's head, and Maureen's thoughts allow readers to experience her own confusion and insecurity about life. Not only does Maureen have abusive relationships with her mother (the "Sarge") and with her boyfriend (Bo), but her internal voice is abusive as well. In fact, it convinces her that "she was a sad, useless, beat-up, knocked-up loser who was too stupid to ever get anywhere" (108). Her depression and insecurity lead her to accept all the violence she experiences because she feels that she is not good enough. Slowly, she learns how to fight her insecurity and deal with her mental health issues: "Maureen knew she had to stop having this internal dialogue because Maureen's mind was definitely not her friend" (185). She ultimately gains the strength necessary to break free of the negativity that has impacted her for so long: "Maureen's mind mocked her ... Oh fuck off, Maureen said to her mind. Just fuck all the way off" (290). Rising up against her own mind and depression allows her to move on and take the courage needed to improve her condition.

Maureen's pregnancy completely changes her life. The emptiness she feels throughout the book reflects the gap left by the baby she was forced to give up for adoption. When she realizes that what she really wants in life is to find her baby, she is able to connect all the dots: "At last, she knew where her baby was, and now that she knew, everything was going to have to change. She was going to have to go back to Montreal and find the baby. With the baby in her arms, she would finally be able to fill in that hole that had been gaping in the middle of her for so long" (241). What she had wanted all along was to be loved. When she was pregnant, the thought of keeping the baby had given 
her the hope to finally be loved "the way she wanted to be" (59). Being separated from her child left her lonely and empty. She "was afraid that her life without the baby had no meaning" (96). Finding the adoption papers and getting a step closer to being reunited with her child changes her and takes away all the insecurity that had dragged her down for so long.

The story is a circle, and ends where it all began: with Maureen flying to Montreal. The same place where her life started to collapse is where she is hoping to rise back again. Walsh chooses a powerful image of St. John's to end her novel: "Maureen looked out the window. They'd said on the radio that morning that fog was generally all over the island portion of Newfoundland, and there it was, still rolling in, obscuring Bell Island, blanketing every part of the heath barrens, shrouding the treeless hills of the Avalon, concealing the vast emptiness of the interior. As she saw how the fog covered the island, Maureen felt downhearted, realizing how long she'd been living in a fog.... Then the fog disappeared and they were flying above the clouds, racing across the clear blue sky, headed west, following the sun" (324-5). The fog covering Newfoundland reflects the fog that has pervaded Maureen's life for so long, and as she gets closer to her baby and to Montreal, she is finally able to see the sun.

An avid reader herself, Walsh, in an interview with Shelagh Rogers, explains that with Crying for the Moon she wanted to open a door for her readers so they could experience lives they would not normally have access to. Walsh skilfully succeeds in her objective, and provides her readers with more than an escape: Crying for the Moon is an educational and entertaining novel about the difficulties of growing up and the impact of our choices.

Francesca Boschetti Memorial University of Newfoundland 